\title{
Effect of Substitution of Fermented King Oyster Mushroom By-Products Diet on Pork Quality during Storage
}

\author{
Gyo Moon Chu, Suk Nam Kang, Hoi Yun Kim ${ }^{1}$, Ji Hee Ha${ }^{1}$, Jong Hyun Kim${ }^{1}$, Min Seob Jung ${ }^{1}$, Jang Woo Ha \\ Sung Dae Lee ${ }^{2}$, Sang Keun $\mathrm{Jin}^{1}$, II Suk Kim ${ }^{1}$, Dae Keun Shin ${ }^{3}$, and Young Min Song ${ }^{1 *}$ \\ Swine Science \& Technology Center, Gyeongnam National University of Science and Technology, Jinju 660-758, Korea \\ ${ }^{1}$ Department of Animal Resources Technology, Gyeongnam National University of Science and Technology, Jinju 660-758, Korea \\ ${ }^{2}$ Swine Science Division, National Institute of Animal Science, Rural Development Administration, Sunghwan 330-801, Korea \\ ${ }^{3}$ Institute of Agricultural Science and Technology, Chonbuk National University, Jeonju 561-756, Korea
}

\begin{abstract}
This study was carried out to investigate the effects of substitution of fermented king oyster mushroom (P. eryngii) by-products diet on pork meat quality characteristics, during the storage. A mixture of $40 \%$ king oyster mushroom by-products, $28 \%$ soybean meal and $20 \%$ corn was fermented for $10 \mathrm{~d}$, and the basal diet was then substituted by the fermented diet mixture of up to 20,50 and $80 \%$, respectively. A total of 96 pigs were fed experimental diet ( 8 pigs per pen $\times 4$ diets $\times 3$ replication), and eight longissiumus (LD) per treatment were collected, when each swine reached to $110 \mathrm{~kg}$ of body weight. The Warner-Bratzler shear forces and cooking loss were significantly lowered in the treatments, while crude protein content and water holding capacity significantly $(p<0.05)$ increased in the treatments than in the control group. The volatile basic nitrogen $(\mathrm{VBN})$, at $1 \mathrm{~d}$ of storage, was lower in the treatments, while texture profiles and sensory evaluation did not differ between the control and the treatments $(p>0.05)$. The $\mathrm{pH}$, thiobarbituric acid reactive substances (TBARS), VBN and meat color in all treatments were increased as storage increased. Fermented king oyster mushroom by-products diet effects on lightness (CIE ${ }^{*}$ ), yellowness $\left(\mathrm{CIE}^{*}\right)$ and chroma were determined, when LD muscles in T2 and T3 treatments were higher $(p<0.05)$, up to $7 \mathrm{~d}(p<0.05)$. Therefore, the results indicate that the substitution of the fermented king oyster mushroom by-products diet to swine diet influenced the quality of the meat and it may be an economically valuable ingredient.
\end{abstract}

Key words: by-products, fermented diet, king oyster mushroom, meat quality, swine

\section{Introduction}

Due to increased health conscious consumers in food market, rapid development in mushroom industry is performed and mushroom is produced up to 1.90 million ton per year in Korea (Kim et al., 2007). The amount of mushroom by-products has also been sharply increased, and many mushroom planters tried to find a way to dispose mushroom by-products right after cultivation. It may generate problems in near future. Therefore, the use of mushroom by-products must be considered. The media used for mushroom cultivation mainly contain cotton waste, corn cob and rice straw with a small amount of rice bran, wheat bran, beet pulp and dried okara (Bae et

\footnotetext{
*Corresponding author: Young Min Song, Department of Animal Resources Technology, Gyeongnam National University of Science and Technology, Jinju 660-758, Korea. Tel: 82-55-751-3588, Fax: 82-55-751-3689, E-mail: pigsong@gntech.ac.kr.
}

al., 2006). These can be considered as dietary ingredients due to available nutrients. According to a paper conducted by Williams et al. (2001), the mushroom cultivation media contain approximately $80 \%$ available nutrients because the mushroom uses only $20 \%$ of the nutrients in the cultivation media. However, the mushroom by-products can easily be contaminated by fungi and bacteria (Kim et al., 2007), and such deterioration is due to high content of moisture in mushroom cultivation media (Kwak et al., 2008). Enhanced storage condition for mushroom by-products must be supplied, the use of mushroom byproducts in Korea will be limited.

Fermentation is a relatively cost-effective and a low energy preservation process, ensuring the shelf-life and microbiological safety of the products (Liu et al., 2011). Fermented diet has been subjected to the actions of the microorganism or enzyme, so desirable biochemical changes can be generated. Steinkraus (1996) reported that fermentation has played at least five different roles including i) 
enrichment of the diet through development of a diversity of flavors, aromas and textures in substrates; ii) preservation through lactic acid, alcoholic, acetic acid and alkaline fermentations; iii) biological enrichment of substrates with proteins, essential amino acids, essential fatty acids and vitamins; iv) detoxification during fermentation processing and $v$ ) decrease in cooking times and fuel requirements. Lactic acid bacteria (LAB) are the most common microorganism in the fermented diet, and their crucial function is mainly associated with their physiological features, including substrate utilization, metabolic capabilities and pro-biotic properties (Liu et al., 2011). Therefore, the LAB (e.g. Lactobacillus plantarum) was selected as a microorganism applied to this experiment.

Fermented by-products diet sources were used, such as oyster mushroom by-products (Song et al., 2007), coproducts of apple (Lee et al., 2009) and agro by-products (Kang et al., 2010). King oyster mushroom (P. eryngii), a major mushroom produced in Korea, is rich, thereby, the use of by-products production due to increased King oyster mushroom cultivation must be considered. Commonly, the king oyster mushroom by-product diet fermented by L. plantarum and Saccharomyces cerevisiae, improved the crude protein $(\mathrm{CP})$ content and total calorie at the end of fermentation as compared to that of initial fermentation. In spite of this, the fermented diet decreased the growth performance of swine and economically unacceptable (Song et al., 2011). Due to a study conducted by Chu et al. (2011), the fermented diet improved carcass grade in swine, and it seems that the fermented diet is now economically valuable. Therefore, this study was conducted to investigate the effects of fermented king oyster mushroom (P. eryngii) by-product diet on the pork meat quality characteristics during 1 and $7 \mathrm{~d}$ of storage.

\section{Materials and Methods}

\section{Animal and diet}

Pigs at the age of $130 \mathrm{~d}$ and average body weight (BW) of $73.15 \pm 6.77 \mathrm{~kg}$ were used, and total 96 pigs were randomly assigned to four different treatments based on BW and gender $(8 \times 3 \times 4=$ pigs $\times$ replication $\times$ treatments; 4 female and 4 barrow per treatment). In order to provide a fermented king oyster mushroom by-products diet, $40.0 \%$ king oyster mushroom (P. eryngii) by-products, $28.0 \%$ soybean meal, $20.0 \%$ corn, $9.82 \%$ rice bran, $1.0 \%$ sugar, $1.0 \%$ corn oil, $0.08 \%$ cellulose and $0.1 \%$ probiotics were mixed. For the $0.1 \%$ probiotics addition, $3.0 \times 10^{7} \mathrm{CFU}$ lactic acid bacteria (L. plantarum), 2.0 $\times 10^{7} \mathrm{CFU}$ Entero- coccus faecium and $2.0 \times 10^{7} \mathrm{CFU}$ yeast (S. cerevisiae) per gram were used. After $24 \mathrm{~h}$ of the mixing process, the mixture was transferred to anaerobic plastic containers and then fermented at room temperature for $10 \mathrm{~d}$.

All pigs were fed with a basal diet (Control, C) containing $33.5 \%$ corn, $30.0 \%$ wheat and $12.5 \%$ soybean meal, and a diet substituted a basal diet to 20 (T1), 50 (T2) and $80 \%$ (T3) fermented king oyster mushroom by-products, respectively (Table 1). All pigs were slaughtered when they were reached at $110 \mathrm{~kg}$ at the end of feed trial. During the experiment, all actions were approved by the Committee on Animal Experimentation of Gyeongnam National University of Science and Technology and conducted in compliance with the Guide lines for the Care and Use of Laboratory Animals. Total 8 longissiumus (LD) (6th to 13th rib) from each treatment was collected and used for the determination of chemical composition and sensory evaluation. Additionally, to determine the $\mathrm{pH}$, thiobarbituric acid reactive substances (TBARS), volatile basic nitrogen (VBN) and parameters of meat color, every

Table 1. Composition of experimental diet

\begin{tabular}{lc}
\hline \multicolumn{1}{c}{ Ingredient } & Percentage (\%) \\
\hline Corn & 33.50 \\
Wheat & 30.00 \\
Soybean meal & 12.50 \\
Tallow & 4.20 \\
Wheat bran & 4.00 \\
Molasses & 4.00 \\
Rapeseed meal & 3.00 \\
Cotton seed meal & 3.00 \\
Palm kernel meal & 2.00 \\
Rice bran & 1.00 \\
Limestone & 1.45 \\
Calcium phosphate, tribasis & 0.60 \\
Sodium chloride & 0.30 \\
L-lysine hydrochloric acid & 0.20 \\
Vitamin premix ${ }^{1)}$ & 0.10 \\
Trace mineral premix ${ }^{2)}$ & 0.10 \\
Phytase & 0.05 \\
\hline Chemical composition ${ }^{3)}$ & \\
Crude protein & 15.50 \\
ME, Mcal/kg & 3.22 \\
Lysine & 0.87 \\
Calcium & 0.70 \\
Total phosphorus & 0.50 \\
\hline
\end{tabular}

${ }^{1)}$ Supplied per kilogram of diet: 4000 IU vitamin A, 3800 IU vitamin D, 1500 IU vitamin E, $150 \mathrm{mg}$ vitamin $\mathrm{K}, 320 \mathrm{mg}$ vitamin $\mathrm{B}_{12}, 11.0 \mathrm{mg}$ niacin, $16.0 \mathrm{mg}$ thiamin, $2.0 \mathrm{mg}$ pantothenic acid, $8.0 \mathrm{mg}$ riboflavin and $0.02 \mathrm{mg}$ Biotin

${ }^{2)}$ Supplied per kilogram of diet: $100 \mathrm{mg} \mathrm{Zn,} 175 \mathrm{mg} \mathrm{Fe}, 90 \mathrm{mg}$ $\mathrm{Mn}, 30 \mathrm{mg} \mathrm{Cu}, 0.50 \mathrm{mg}$ Co, $0.20 \mathrm{mg}$ Se and $0.30 \mathrm{mg} \mathrm{I}$

${ }^{3)}$ Calculated values 
sample was vacuum packaged, stored at $4^{\circ} \mathrm{C}$ and then used on day 1 and 7 of storage.

\section{Determination of crude protein content, backfat sur-} face color, water holding capacity and cooking loss

The Kjeldhal method (\#984.13) of AOAC (1995) was used for crude protein determination. Approximately, $1 \mathrm{~g}$ of ground LD was weighed, added to a digestion flask, and a series of sample digestions and distillations was conducted. Each sample was then titrated with a sodium hydroxide and expressed as a percent (\%).

Fat and meat color of LD were evaluated on freshly cut surface ( $3 \mathrm{~cm}$ thick slice) using a Chroma Meter CR-300 (Minolta, Osaka, Japan) after 20 min of blooming at the room temperature (RT). Five color measurements were carried out across individual sample surface, and the average was expressed as CIE L ${ }^{*}, \mathrm{CIE} \mathrm{a}^{*}, \mathrm{CIE} \mathrm{b}{ }^{*}$, Chroma and Hue angle. The Chroma Meter CR-300 was calibrated against a white tile $\left(\mathrm{L}^{*}=93.30, \mathrm{a}^{*}=0.32\right.$ and $\left.\mathrm{b}^{*}=0.33\right)$ based on a daily basis. Chroma (saturation) and Hue angle were calculated as $\left(\mathrm{a}^{* 2}+\mathrm{b}^{* 2}\right)^{1 / 2}$ and $\arctan \mathrm{b}^{*} / \mathrm{a}^{*}$ (Wyszcecki and Stiles, 1982).

Both water holding capacity (WHC) and cooking loss were determined as described by Honikel (1998). Samples were cut $(2.0 \mathrm{~cm} \times 0.4 \mathrm{~cm} \times 0.4 \mathrm{~cm})$, weighed and placed in tubes with a filter to separate the meat from the expelled liquid in the bottom of the tubes. The samples were centrifuged (Combi-514R, Hanil, Incheon, Korea) at $40 \mathrm{~g}$ for $1 \mathrm{~h}$ at $4^{\circ} \mathrm{C}$, and then the loss was calculated as the difference in weight before and after centrifugation. For the cooking loss, $80 \mathrm{~g}$ of $1.5 \mathrm{~cm}$ thick LD was placed in a polyethylene bag. The packages were then kept in a water bath (DS-23S, Dasol, Hwaseong, Korea) at $75^{\circ} \mathrm{C}$ for $1 \mathrm{~h}$ and cooled at RT for $30 \mathrm{~min}$. The cooking loss percentage was determined using the muscle weight that was taken before and after cooking.

\section{Determination of fatty acid composition}

For the determination of fatty acids composition, total lipid was extracted using a modified Folch method as described by Ways and Hanahan (1964), and then saponification and esterification was conducted using a $0.5 \mathrm{~N}$ potassium hydroxide in methanol and $14 \%$ boron trifluoride methanol solution. Finally, the fatty acid methyl esters (FAME) in the hexane were injected to a gas chromatography (Agilent 6890+, Agilent HP, USA) fitted with a capillary column (HP-5MS capillary GLC column, $30 \mathrm{~m} \times 0.32 \mathrm{~mm}$ i.d. $0.25 \mathrm{~mm}$ film thickness, Agilent HP, USA) and a mass spectrometry detector (G1530A, Agilent
HP, USA). The mass spectrometry interface and injector temperature were fixed at $270^{\circ} \mathrm{C}$ and $260^{\circ} \mathrm{C}$, respectively, and oven temperature was instituted to $160^{\circ} \mathrm{C}$ at $2.5 \mathrm{~min}$, 160 to $260^{\circ} \mathrm{C}$ at $4^{\circ} \mathrm{C}$ per min and then $260^{\circ} \mathrm{C}$ at $5 \mathrm{~min}$. Each fatty acid was identified by comparing their retention times with those of FAME standard (FAME Mix C8C24, Supelco, PA, USA) and expressed as a percentage of standards.

\section{Determination of WBSF, TPA and sensory evaluation}

Warner-Bratzler shear force (WBSF) was determined as described by Honikel (1998). Each LD was prepared into a cube of $4 \mathrm{~cm} \times 2.5 \mathrm{~cm} \times 1.5 \mathrm{~cm}$ (length $\times$ width $\times$ height) and then cooked and cooled. The WBSF was measured using an Instron 3343 (US/MX50, A\&D Co., USA) equipped with a Warner-Bratzler shearing device providing a $100 \mathrm{~mm} / \mathrm{min}$ crosshead speed. The average shear force value from each treatment was calculated and expressed as $\mathrm{kg} / \mathrm{cm}^{2}$.

Texture profile analysis (TPA) of eight samples $(2 \mathrm{~cm}$ $\times 2 \mathrm{~cm} \times 2 \mathrm{~cm}$ ) from each treatment was assessed using an Instron 3343 (US/MX50, A\&D Co., USA) equipped with a cylindrically shaped plunger (5-mm diameter) and a 500N load cell (Bourne, 1978; Szczceniak, 1963; Texture Technologies, 2003). To determine texture parameters including brittleness, hardness, cohesiveness, springness, gumminess, chewiness and adhesiveness, each cube sample was equilibrated to a room temperature and compressed twice to $50 \%$ of its original thickness at a constant speed of $60 \mathrm{~mm} / \mathrm{min}$. Texture profile parameters were calculated from the force deformation curves as follows: hardness ( $\mathrm{kg}$ f; force necessary to attain a given deformation, maximum force), cohesiveness (dimensionless, ratio; ratio of the positive force area during the second compression to that during the first compression excluding the areas under the decompression portion of each cycle), springness (ratio; ratio of distances that the samples recover after the first compression), gumminess (kg f; simulated energy required to disintegrate a semisolid food to a steady state, hardness $\times$ cohesiveness $)$ and chewiness $(\mathrm{kg}$ $\mathrm{f}$; hardness $\times$ cohesiveness $\times$ springness).

For sensory evaluation, a total of 35 panelists were participated and conducted in duplicate on each sample. Training of panelists was performed according to a sensory evaluation guideline (Meilgaard et al., 1991). The meat samples were cooked to an internal temperature of $74^{\circ} \mathrm{C}$ in a water bath and then the samples were cut into $10 \times 3 \times 25 \mathrm{~mm}^{3}$ pieces, placed on white plastic trays covered with aluminum foil and served immediately to each 
panelist. The cooked meat samples were evaluated for color $(1=$ very unacceptable; $9=$ very acceptable $)$, off-flavor $(1=$ very weak; $9=$ very strong $)$, juiciness $(1=$ very dry; $9=$ very juicy $)$, flavor $(1=$ very unacceptable; $9=$ very acceptable), tenderness $(1=$ very tough; $9=$ very tender $)$ and total acceptability $(1=$ very unacceptable; $9=$ very acceptable).

\section{Determination of $\mathrm{pH}, \mathrm{TBARS}, \mathrm{VBN}$ and meat color during storage}

To determine the $\mathrm{pH}$ value, a $10 \mathrm{~g}$ sample was homogenized with a $90 \mathrm{~mL}$ of double distilled water (DDW) for $20 \mathrm{~s}$ at 13,500 rpm (T25B, IKA Sdn. Bhd., Malaysia). The pH meter (Hanna HI 9025, Woonsocket, RI, USA) with an Orion 8163 glass electrode (Berverly, MA, USA) was used, and duplicate reading per sample was performed. Prior to record the $\mathrm{pH}$ value, the $\mathrm{pH}$ meter was calibrated daily basis using standard buffers at $\mathrm{pH} 4.0$ and 7.0.

The TBARS analysis described by Huang and Miller (1993) was performed to determine the degree of lipid oxidation. Three grams of each meat sample were weighed and mixed with a $57 \mathrm{~mL}$ phosphate buffer $(\mathrm{pH}$ 7.0). The mixtures were then homogenized at $12,000 \mathrm{~g}$ for $1 \mathrm{~min}$ (T25B, IKA Sdn. Bhd., Malaysia). The homogenized samples were incubated, cooled and centrifuged at 2,000 rpm for $15 \mathrm{~min}$. The supernatants were collected, read, calculated and expressed as $\mathrm{mg}$ malonaldehyde $/ \mathrm{kg}$ of LD muscle tissue.

The VBN analysis was conducted as described to Pearson (1976) and expressed as mg VBN/100 g of sample. Briefly, $1 \mathrm{~g}$ of sample and a few drops of phenolphthalein indicator were mixed with a $3.5 \mathrm{~mL} 20 \%$ sodium hydroxide solution in a distillated flask. The apparatus was tightly sealed, and steam distillate was collected in a flask containing a $20 \mathrm{~mL} 4 \%$ boric acid and a few drops of methyl red and methylene blue. The steam distillate was continuously collected until a $250 \mathrm{~mL}$ distillated flask was filled. The solution obtained was then titrated using a $0.01 \mathrm{M}$ hydrochloric acid, and titration was stopped when the green color changed to gray. The final VBN calculation was accomplished based on a VBN value from a blank containing $6 \%$ perchloric acid steam distillation.

\section{Statistical Analyses}

For general data of LD from each treatment, data were analyzed with one-way ANOVA, and significant differences among diet types and sex were determined using Fisher's LSD method. Additionally, to determine data collected during storage, the changes in $\mathrm{pH}$, TBARS, VBN and meat color were analyzed using a two-way ANOVA, and the model included sex, diet type and storage period. Significant differences were determined using Fisher's LSD method as well. All analyses were conducted using the General Linear Model (GLM) procedure of SAS (1999) and significant differences among the means were determined using the Duncan's Multiple Range Test method $(p<0.05)$.

\section{Results}

\section{Crude protein content, backfat surface color, cook- ing loss and water holding capacity}

Crude protein content was not influenced due to the gender but affected by the diet (Table 2), and CP content was significantly increased in $\mathrm{T} 2$ and $\mathrm{T} 3$ than in $\mathrm{C}$ and $\mathrm{T} 1$ $(p<0.05)$.

The substitution of fermented king oyster mushroom by-products diet to swine diet showed an influence on the lightness (CIE L*) and the hue angle (Table 2), and the lightness was significantly higher in $\mathrm{T} 3$ as compared to that of others $(p<0.05)$. Hue angel values were significantly higher in treatments than in $\mathrm{C}$ and were not different between treatments.

The substitution of fermented king oyster mushroom by-products diet had an effect on both cooking loss and WHC (Table 2). Cooking loss was significantly lowered when both $\mathrm{T} 2$ and $\mathrm{T} 3$ diets were fed to pigs, in contrast, WHC showed higher values in $\mathrm{T} 2$ and $\mathrm{T} 3$ treatments than in $\mathrm{C}$ and was significantly higher in $\mathrm{T} 3$ than $\mathrm{C}$ and $\mathrm{T} 1$ $(p<0.05)$.

\section{Fatty acid composition}

The palmitic acid, stearic acid and linolenic acid composition were similar across treatments, while composition of myristic acid, oleic acid, linoleic acid and arachidonic acid were affected due to the substitution of fermented king oyster mushroom by-products diet (Table 3). It seems that high myristic acid was composed when fermented king oyster mushroom by-products diet was supplied to diet and then fed to pigs, however, lower composition was determined as fermented king oyster mushroom by-products diet was supplied to pigs for $52 \mathrm{~d}$ $(p<0.05)$. Additionally, it appears that linoleic acid composition was not highly arranged but tended to compose more arachidonic acid in LD muscle as fermented king oyster mushroom by-products diets were fed to pigs $(p<0.05)$. More saturated fatty acid (SFA) and less unsat- 
Table 2. Crude protein content, backfat surface color, cooking loss and water holding capacity of swine longissimus dorsi muscle fed with different levels of fermented king oyster mushroom by-products diet

\begin{tabular}{|c|c|c|c|c|c|c|c|}
\hline \multirow{2}{*}{ Items } & \multicolumn{4}{|c|}{ Treatment $^{1)}$} & \multirow{2}{*}{ SEM $^{4)}$} & \multicolumn{2}{|c|}{$\mathrm{p}$} \\
\hline & $\mathrm{C}$ & $\mathrm{T} 1$ & $\mathrm{~T} 2$ & $\mathrm{~T} 3$ & & Sex & Diet \\
\hline \multicolumn{8}{|l|}{ Proximate Composition } \\
\hline Crude protein (\%) & $21.13^{b}$ & $22.67^{\mathrm{ab}}$ & $23.13^{\mathrm{a}}$ & $23.07^{\mathrm{a}}$ & 0.77 & - & $*$ \\
\hline \multicolumn{8}{|l|}{ Backfat surface color ${ }^{2)}$} \\
\hline Lightness (CIE L $\left.{ }^{*}\right)$ & $78.82^{b}$ & $79.65^{b}$ & $79.53^{b}$ & $81.48^{\mathrm{a}}$ & 1.82 & - & $*$ \\
\hline Redness (CIE a $\left.{ }^{*}\right)$ & 0.80 & 0.43 & 0.45 & 0.49 & 0.45 & - & - \\
\hline Yellowness (CIE b*) & 8.89 & 8.21 & 8.35 & 8.51 & 0.80 & - & - \\
\hline Chroma & 8.92 & 8.25 & 8.41 & 8.79 & 0.70 & - & - \\
\hline Hue angle & $87.00^{\mathrm{b}}$ & $93.81^{\mathrm{a}}$ & $94.91^{\mathrm{a}}$ & $93.58^{\mathrm{a}}$ & 4.97 & - & $*$ \\
\hline \multicolumn{8}{|l|}{ Physical property } \\
\hline Cooking loss (\%) & $26.82^{\mathrm{a}}$ & $23.74^{\mathrm{ab}}$ & $22.93^{b}$ & $21.99^{b}$ & 4.02 & - & $*$ \\
\hline $\mathrm{WHC}^{3)}(\%)$ & $62.90^{\mathrm{c}}$ & $63.49^{\mathrm{bc}}$ & $67.42^{\mathrm{ab}}$ & $68.32^{\mathrm{a}}$ & 0.76 & - & $*$ \\
\hline
\end{tabular}

${ }^{1)}$ The basal diet was substituted by the fermented king oyster mushroom by-products diet: $\mathrm{C}$, no substitution; T1, 20\%; T2, 50\% and T3, 80\%.

${ }^{2)}$ Chroma, $\left(a^{* 2}+b^{* 2}\right)^{1 / 2}$ and hue angle, $b^{*} / a^{*}$

${ }^{3)}$ Water Holding Capacity

${ }^{4)}$ Standard error of the means and * stands for $p<0.05$

${ }^{\mathrm{a}, \mathrm{b}, \mathrm{c}}$ Mean values within a row followed by the same letter are not significantly different $(p>0.05)$.

Each data point represents the mean of 8 observations ( 4 female and 4 barrow).

Table 3. Fatty acid profiles of swine longissimus dorsi muscle fed with different levels of fermented king oyster mushroom by-products diet

\begin{tabular}{|c|c|c|c|c|c|c|c|}
\hline \multirow{2}{*}{ Items } & \multicolumn{4}{|c|}{ Treatment $^{1)}$} & \multirow{2}{*}{$\mathrm{SEM}^{5)}$} & \multicolumn{2}{|c|}{$\mathrm{p}$} \\
\hline & $\mathrm{C}$ & $\mathrm{T} 1$ & $\mathrm{~T} 2$ & T3 & & Sex & Diet \\
\hline C14:0 & $10.26^{\mathrm{b}}$ & $14.46^{\mathrm{ab}}$ & $22.43^{\mathrm{a}}$ & $11.53^{\mathrm{ab}}$ & 4.72 & - & $*$ \\
\hline C16:0 & 22.82 & 22.54 & 21.03 & 21.76 & 1.15 & - & - \\
\hline C18:0 & 9.12 & 9.88 & 8.91 & 9.55 & 0.48 & - & - \\
\hline C18:1 & $41.33^{\mathrm{a}}$ & $36.66^{\mathrm{b}}$ & $33.89^{\mathrm{b}}$ & $30.51^{\mathrm{c}}$ & 3.94 & - & $*$ \\
\hline C18:2 & $13.13^{\mathrm{ab}}$ & $12.69^{\mathrm{b}}$ & $10.09^{\mathrm{b}}$ & $19.87^{\mathrm{a}}$ & 5.31 & - & $*$ \\
\hline C18:3 & 0.25 & 0.29 & 0.15 & 0.29 & 0.26 & - & - \\
\hline C20:4 & $3.10^{\mathrm{b}}$ & $3.52^{\mathrm{b}}$ & $3.50^{\mathrm{b}}$ & $6.49^{\mathrm{a}}$ & 1.33 & - & $*$ \\
\hline SFA $^{2)}$ & $42.20^{\mathrm{b}}$ & $46.89^{\mathrm{ab}}$ & $52.32^{\mathrm{a}}$ & $42.85^{\mathrm{b}}$ & 4.16 & - & $*$ \\
\hline $\mathrm{UFA}^{3)}$ & $57.80^{\mathrm{a}}$ & $53.11^{\mathrm{ab}}$ & $47.62^{b}$ & $57.15^{\mathrm{a}}$ & 4.16 & - & $*$ \\
\hline $\mathrm{EFA}^{4)}$ & $13.35^{\mathrm{b}}$ & $12.98^{\mathrm{b}}$ & $10.24^{\mathrm{b}}$ & $20.16^{\mathrm{a}}$ & 7.12 & - & $*$ \\
\hline UFA/SFA & 1.37 & 1.16 & 0.93 & 1.34 & 0.16 & - & - \\
\hline
\end{tabular}

${ }^{1)}$ The basal diet was substituted by the fermented king oyster mushroom by-products diet: C, no substitution; T1, 20\%; T2, $50 \%$ and $\mathrm{T} 3,80 \%$.

${ }^{2)}$ Saturated Fatty Acid $=\mathrm{C} 14: 0+\mathrm{C} 16: 0+\mathrm{C} 18: 0$

${ }^{3)}$ Unsaturated Fatty Acid $=\mathrm{C} 18: 1+\mathrm{C} 18: 2+\mathrm{C} 18: 3+\mathrm{C} 20: 4$

${ }^{4)}$ Essential Fatty Acid $=\mathrm{C} 18: 2+\mathrm{C} 18: 3$

${ }^{5)}$ Standard error of the means and * stands for $p<0.05$

${ }^{\mathrm{a}-\mathrm{c}}$ Mean values within a row followed by the same letter are not significantly different $(p>0.05)$.

Each data point represents the mean of 8 observations ( 4 female and 4 barrow).

urated fatty acid (UFA) were determined in T1 and T2 than those in C and T3 $(p<0.05)$, and essential fatty acid composition was only differed in T3 $(p<0.05)$.
Table 4. WBSF, texture profiles and sensory evaluation of swine longissimus dorsi muscle fed with different levels of fermented king oyster mushroom by-products diet

\begin{tabular}{|c|c|c|c|c|c|c|c|}
\hline \multirow{2}{*}{ Items } & \multicolumn{4}{|c|}{ Treatment $^{1)}$} & \multirow{2}{*}{$\mathrm{SEM}^{4)}$} & \multicolumn{2}{|c|}{$\mathrm{p}$} \\
\hline & $\mathrm{C}$ & $\mathrm{T} 1$ & $\mathrm{~T} 2$ & T3 & & Sex & Diet \\
\hline $\operatorname{WBSF}^{2)}\left(\mathrm{kg} / \mathrm{cm}^{2}\right)$ & $4.41^{\mathrm{a}}$ & $4.06^{\mathrm{ab}}$ & $3.96^{\mathrm{bc}}$ & $3.82^{\mathrm{c}}$ & 0.47 & - & $*$ \\
\hline \multicolumn{8}{|c|}{ Texture profile analysis } \\
\hline Hardness & 1.07 & 1.16 & 1.13 & 1.11 & 0.17 & - & - \\
\hline Surface hardness & 1.00 & 1.10 & 1.08 & 1.11 & 0.17 & - & - \\
\hline Cohesiveness & 0.37 & 0.46 & 0.39 & 0.40 & 0.09 & - & - \\
\hline Springness & 1.00 & 1.14 & 1.08 & 1.12 & 0.11 & - & - \\
\hline Gumminess & 0.39 & 0.56 & 0.43 & 0.45 & 0.14 & - & - \\
\hline Chewiness & 0.39 & 0.64 & 0.47 & 0.52 & 0.20 & - & - \\
\hline Adhesiveness & 0.20 & 0.20 & 0.15 & 0.17 & 0.05 & - & - \\
\hline
\end{tabular}

Sensory evaluation ${ }^{3)}$

Color

Aroma

Flavor

Tenderness

Texture

$\begin{array}{lllll}4.33 & 4.35 & 3.30 & 4.13 & 1.51\end{array}$

$\begin{array}{lllll}4.23 & 4.10 & 4.48 & 4.27 & 0.89\end{array}$

$\begin{array}{lllll}4.37 & 4.30 & 4.08 & 4.20 & 1.44\end{array}$

$\begin{array}{lllll}4.83 & 4.83 & 4.18 & 4.37 & 1.05\end{array}$

$\begin{array}{lllllllll}\text { Overall acceptability } & 4.88 & 4.64 & 4.13 & 4.70 & 1.26 & - & -\end{array}$

${ }^{1)}$ The basal diet was substituted by the fermented king oyster mushroom by-products diet: C, no substitution; T1, 20\%; T2, $50 \%$ and $\mathrm{T} 3,80 \%$.

${ }^{2)}$ Warner-Bratzler shear force

${ }^{3)}$ Sensory evaluation were scored on 9 point scale based on 1 (extremely bad) to 9 (extremely good).

${ }^{4)}$ Standard error of the means and $*$ stands for $p<0.05$.

${ }^{\text {a-c) }}$ Mean values within a row followed by the same letter are not significantly different $(p>0.05)$.

Each data point represents the mean of 8 observations ( 4 female and 4 barrow). 


\section{WBSF, Texture profile and sensory evaluation}

The WBSF was significantly lowered in $\mathrm{T} 2$ and $\mathrm{T} 3$ than in $\mathrm{C}$ and had a lower value in $\mathrm{T} 3$ than in $\mathrm{C}$ and $\mathrm{T} 1$ (Table 4) $(p<0.05)$. However, the partial substitution of fermented king oyster mushroom by-products diet to the swine diet did not affect texture profile and sensory evaluation of LD muscles (Table 4).

\section{Changes of $\mathbf{p H}$, TBARS and VBN during storage}

The $\mathrm{pH}$ and TBARS at day 1 and 7 of storage were not affected due to the diet (Table 5) $(p>0.05)$. However, the VBN at $1 \mathrm{~d}$ was significantly influenced by the substitution of fermented king oyster mushroom by-products diet, while VBN at $7 \mathrm{~d}$ was not affected. The VBN at day 1 of storage was significantly lowered in treatments than in $\mathrm{C}$

Table 5. pH, TBARS and VBN of swine longissimus dorsi muscle fed with different levels of fermented king oyster mushroom byproducts diet

\begin{tabular}{|c|c|c|c|c|c|c|c|}
\hline \multirow{2}{*}{ Items } & \multirow{2}{*}{$\begin{array}{l}\text { Storage } \\
\text { periods }\end{array}$} & \multicolumn{4}{|c|}{ (Treatment ${ }^{1)}$} & \multicolumn{2}{|c|}{$\mathrm{P}$} \\
\hline & & $\mathrm{C}$ & $\mathrm{T} 1$ & $\mathrm{~T} 2$ & $\mathrm{~T} 3$ & Sex & Diet \\
\hline \multirow{3}{*}{$\mathrm{pH}$} & 1 & $4.62 \pm 0.02^{\mathrm{B}}$ & $4.69 \pm 0.15^{\mathrm{B}}$ & $4.79 \pm 0.17^{\mathrm{B}}$ & $4.56 \pm 0.14^{\mathrm{B}}$ & - & - \\
\hline & 7 & $5.10 \pm 0.32^{\mathrm{A}}$ & $5.14 \pm 0.14^{\mathrm{A}}$ & $5.28 \pm 0.23^{\mathrm{A}}$ & $5.17 \pm 0.09^{\mathrm{A}}$ & - & - \\
\hline & $\mathrm{p}$ & $*$ & $*$ & * & $*$ & & \\
\hline \multirow{3}{*}{$\begin{array}{c}\text { TBARS }^{2} \\
\text { (mg malonaldehyde/kg) }\end{array}$} & 1 & $0.31 \pm 0.03^{\mathrm{B}}$ & $0.29 \pm 0.01^{\mathrm{B}}$ & $0.30 \pm 0.01^{\mathrm{B}}$ & $0.30 \pm 0.01^{\mathrm{B}}$ & - & - \\
\hline & 7 & $0.36 \pm 0.02^{\mathrm{A}}$ & $0.36 \pm 0.08^{\mathrm{A}}$ & $0.35 \pm 0.02^{\mathrm{A}}$ & $0.32 \pm 0.02^{\mathrm{A}}$ & - & - \\
\hline & $\mathrm{p}$ & $*$ & * & * & $*$ & & \\
\hline \multirow{3}{*}{$\begin{array}{c}\mathrm{VBN}^{3)} \\
(\mathrm{mg} / 100 \mathrm{~g})\end{array}$} & 1 & $11.95 \pm 2.95^{\mathrm{aB}}$ & $6.40 \pm 0.27^{\mathrm{bB}}$ & $6.52 \pm 0.74^{\mathrm{bB}}$ & $6.72 \pm 1.96^{\mathrm{bB}}$ & - & $*$ \\
\hline & 7 & $34.33 \pm 5.13^{\mathrm{A}}$ & $40.40 \pm 4.75^{\mathrm{A}}$ & $40.25 \pm 7.01^{\mathrm{A}}$ & $35.07 \pm 1.10^{\mathrm{A}}$ & - & - \\
\hline & $\mathrm{p}$ & $*$ & $*$ & $*$ & $*$ & & \\
\hline
\end{tabular}

${ }^{15}$ The basal diet was substituted by the fermented king oyster mushroom by-products diet: C, no substitution; T1, 20\%; T2, 50\% and T3, 80\%.

${ }^{2)}$ Thiobarbituric Acid Reactive Substances

${ }^{3)}$ Volatile Basic Nitrogen

${ }^{a-c}$ Mean values within a column followed by the same letter are not significantly different $(p>0.05)$.

${ }^{A-C}$ Mean values within a row followed by the same letter are not significantly different $(p>0.05)$.

Data represent the mean \pm SD of 8 observations (4 female and 4 barrow).

Table 6. Meat color of swine longissimus dorsi muscle fed with different levels of fermented king oyster mushroom by-products diet

\begin{tabular}{|c|c|c|c|c|c|c|c|}
\hline \multirow{2}{*}{ Items } & \multirow{2}{*}{$\begin{array}{l}\text { Storage } \\
\text { periods }\end{array}$} & \multicolumn{4}{|c|}{ Treatments $^{1)}$} & \multicolumn{2}{|c|}{$\mathrm{P}$} \\
\hline & & $\mathrm{C}$ & $\mathrm{T} 1$ & $\mathrm{~T} 2$ & $\mathrm{~T} 3$ & Sex & Diet \\
\hline \multirow{3}{*}{$\begin{array}{l}\text { Lightness } \\
(\mathrm{CIE} \mathrm{L*)}\end{array}$} & 1 & $53.59 \pm 1.44^{\mathrm{aB}}$ & $51.44 \pm 4.03^{\mathrm{abB}}$ & $49.59 \pm 2.51^{\mathrm{bB}}$ & $51.98 \pm 2.42^{\mathrm{ab}}$ & - & $*$ \\
\hline & 7 & $57.77 \pm 2.67^{\mathrm{aA}}$ & $55.38 \pm 1.46^{\mathrm{aA}}$ & $53.74 \pm 2.85^{\mathrm{bA}}$ & $54.53 \pm 2.71^{\mathrm{b}}$ & - & $*$ \\
\hline & $\mathrm{P}$ & $*$ & $*$ & $*$ & & & \\
\hline \multirow{3}{*}{$\begin{array}{l}\text { Redness } \\
\left(\mathrm{CIE} \mathrm{a}^{*}\right)\end{array}$} & 1 & $3.07 \pm 1.41$ & $3.04 \pm 1.32$ & $3.72 \pm 1.25$ & $3.12 \pm 1.52$ & - & - \\
\hline & 7 & $3.47 \pm 0.89$ & $3.58 \pm 0.84$ & $3.17 \pm 0.97$ & $2.95 \pm 1.04$ & - & - \\
\hline & $\mathrm{p}$ & - & - & - & - & & \\
\hline \multirow{3}{*}{$\begin{array}{l}\text { Yellowness } \\
\left(\mathrm{CIE} \mathrm{b}^{*}\right)\end{array}$} & 1 & $5.50 \pm 0.73^{\mathrm{B}}$ & $5.12 \pm 1.14^{\mathrm{B}}$ & $5.02 \pm 0.71^{\mathrm{B}}$ & $5.79 \pm 1.05$ & - & - \\
\hline & 7 & $6.99 \pm 0.68^{\mathrm{aA}}$ & $6.56 \pm 0.67^{\mathrm{aA}}$ & $5.77 \pm 0.69^{\mathrm{bA}}$ & $5.60 \pm 0.62^{\mathrm{b}}$ & - & $*$ \\
\hline & $\mathrm{p}$ & $*$ & $*$ & $*$ & - & & \\
\hline \multirow{3}{*}{ (hroma ${ }^{2)}$} & 1 & $6.37 \pm 1.23^{\mathrm{B}}$ & $6.06 \pm 1.27^{\mathrm{B}}$ & $6.02 \pm 1.33$ & $6.32 \pm 1.80$ & - & - \\
\hline & 7 & $7.82 \pm 0.94^{\mathrm{aA}}$ & $7.49 \pm 0.86^{\mathrm{aA}}$ & $6.63 \pm 0.89^{b}$ & $6.39 \pm 0.74^{b}$ & - & $*$ \\
\hline & $\mathrm{p}$ & * & * & - & - & & \\
\hline \multirow{3}{*}{ Hue angle ${ }^{3)}$} & 1 & $62.32 \pm 9.56$ & $59.71 \pm 11.45$ & $50.84 \pm 16.40^{\mathrm{B}}$ & $62.30 \pm 12.39$ & - & - \\
\hline & 7 & $63.90 \pm 4.49$ & $61.69 \pm 5.08$ & $61.69 \pm 6.87^{\mathrm{A}}$ & $62.60 \pm 8.75$ & - & - \\
\hline & $\mathrm{p}$ & - & - & $*$ & - & & \\
\hline
\end{tabular}

${ }^{11}$ The basal diet was substituted by the fermented king oyster mushroom by-products diet: C, no substitution; T1, 20\%; T2, 50\% and T3, 80\%.

${ }^{2)}$ Chroma $=\left(\mathrm{a}^{* 2}+\mathrm{b}^{* 2}\right)^{1 / 2}$

${ }^{3)}$ Hue angle $=b^{*} / a^{*}$

${ }^{\mathrm{a}-\mathrm{c}}$ Mean values within a column followed by the same letter are not significantly different $(p>0.05)$.

${ }^{\mathrm{A}-\mathrm{C}}$ Mean values within a row followed by the same letter are not significantly different $(p>0.05)$.

Data represent the mean \pm SD of 8 observations ( 4 female and 4 barrow). 
but did not differ between treatments. The $\mathrm{pH}$ and TBARS values were increase when LD muscles from all treatments were stored up to $7 \mathrm{~d}$ of storage $(p<0.05)$ but significance was not determined between treatments $(p>0.05)$.

\section{Change of meat color during storage}

The substitution of king oyster mushroom by-products diet affected lightness (CIE L ${ }^{*}$ ) at 1 and $7 \mathrm{~d}$ of storage (Table 6) $(p<0.05)$. Moreover, the diet affected yellowness $\left(\mathrm{CIE} \mathrm{b}^{*}\right)$ and chroma at $7 \mathrm{~d}$, while yellowness (CIE $\mathrm{b}^{*}$ ) and chroma at $1 \mathrm{~d}$ were not influenced. It seems that the substitution of fermented king oyster mushroom by-products diet decreased the lightness (CIE L*), yellowness $\left(\mathrm{CIE} \mathrm{b}^{*}\right)$ and chroma as compared to those of LD muscle at day 1 of storage $(p<0.05)$. However, the diet effects were not determined in the redness (CIE $\mathrm{a}^{*}$ ) and hue angel during storage $(p>0.05)$. Due to the effects of storage on LD color, lightness (CIE L ${ }^{*}$ ) and yellowness (CIE $\left.\mathrm{b}^{*}\right)$ in $\mathrm{C}, \mathrm{T} 1$ and T2 were highly increased in $7 \mathrm{~d}$ than in $1 \mathrm{~d}(p<0.05)$. The LD muscles from $\mathrm{C}$ and $\mathrm{T} 1$ treatments had increased chroma values in $7 \mathrm{~d}$ of storage as compared to that of LD muscle stored up to day 1, and only hue angel of LD from T2 treatment showed a higher value when LD muscles were stored up to $7 \mathrm{~d}(p<0.05)$.

\section{Discussion}

The major purpose of this study was to investigate the effects of fermented king oyster mushroom (P. eryngii) by-product diet on the pork meat quality characteristics during storage. Substitution of fermented king oyster mushroom by-products diet increased $\mathrm{CP}$ content and WHC but decreased lightness (CIE L ${ }^{*}$ ) and cooking loss (Table 2). Typically, the consumption of diet with high energy and fat increased pig backfat thickness (Pettigrew and Moser 1991), and the CP content increased due to decreased crude fat (CF) of meat (Shield et al., 1983). The fermented king oyster mushroom by-products diet had low energy (1.77 to $2.86 \mathrm{Mcal} / \mathrm{kg} \mathrm{ME})$ and fat $(1.66$ to $5.22 \% \mathrm{CF}$ ), and it seems that the $\mathrm{CP}$ content was affected due to the substitution of fermented king oyster mushroom by-products diet to a pig diet. Therefore, WHC increased and cooking loss decreased when fermented king oyster mushroom by-products diet was supplied to pigs for $52 \mathrm{~d}$, and it is similar to results reported by Lee et al. (2009) and Kang et al. (2010). Animal breed, sex, age and feed are common factors influencing meat and fat color, and as mentioned, lightness (CIE L ${ }^{*}$ ) of backfat surface was affected when fermented king oyster mushroom by-products diet was substituted up to $80 \%$. It was similar to a result confirmed by Kang et al. (2010), and they indicated that high carbohydrate-low fat fermented diet increased lightness $\left(\mathrm{CIE} \mathrm{L}^{*}\right)$ of meat in fattening pigs.

The $80 \%$ substitution of fermented king oyster mushroom by-products diet to basal diet increased the composition of linoleic acid, arachidonic acid and essential fatty acid in LD of fattening pigs (Table 3). Song et al. (2007) reported that fermented oyster mushroom by-products diet increased the composition of arachidonic acid in LD of Berkshire pigs, and fatty acid composition of meat is able to be influenced due to the diet (French et al., 2000). Therefore, the fermented king oyster mushroom by-products diet could be a reason of increased fatty acid composition including linoleic acid, arachidonic acid and essential fatty acid, respectively. The substitution of fermented king oyster mushroom by-products diet to the swine diet decreased WBSF, but any significant differences were not determined in texture properties and sensory evaluation as studied by Platter et al. (2003).

The $\mathrm{pH}$ and TBARS were not influenced due to fermented king oyster mushroom by-products diet (Table 5). However, $\mathrm{pH}$ and TBARS were affected when LD muscles were stored up to $7 \mathrm{~d}$, and they were increased as storage period was elapsed. The VBN was also increased during storage, and effects of dietary fermented king oyster mushroom by-products diet were observed as LD muscles were kept at $4^{\circ} \mathrm{C}$ for day 1 of storage, only. The VBN concentration is an important index for estimation of meat freshness because it is increased by the levels of microbial contamination. Meat protein degraded into amino acids by protease and enzymes from microorganisms and amino acids degraded into inorganic nitrogen compounds when levels of microorganism contamination increased (Lee et al., 2006). Moreover, the CP content in LD muscle may positively be affected, but CP content did not provide any effects when LD muscles were stored on day 1 of storage, in contrast it seems that CP content was influenced on the generation of inorganic nitrogen compounds. As a result, similar VBN was determined at $7 \mathrm{~d}$ of storage.

The lightness (CIE L ${ }^{*}$ ) and yellowness $\left(\mathrm{CIE} \mathrm{b}^{*}\right)$ in LD of $\mathrm{C}, \mathrm{T} 1$ and $\mathrm{T} 2$ treatments increased by storage, but $\mathrm{T} 3$ was not affected at all meat color parameters. The evaluation of meat quality was based on meat color, texture and etc., especially, consumer preference is based on meat color in market than other meat quality parameters 
(Risvik, 1994). The change of fresh meat color during storage is affected by many factors, such as $\mathrm{pH}$, storage temperature, oxygen partial pressure, and diet (Lawrie 1985). It seems that fermented king oyster mushroom byproducts diet had an influence on lightness $\left(\mathrm{CIE} \mathrm{L}^{*}\right)$ and yellowness $\left(\mathrm{CIE} \mathrm{b}^{*}\right)$ when fermented king oyster mushroom by-products diet was substituted to diet more than $50 \%$, and such a result was similar to that of Darmadji and Izumimoto (1994) who found the increased meat lightness and yellowness color when fermented diet was supplied to pigs for $10 \mathrm{~d}$ of feeding period.

In conclusion, the results indicate that the fermented king oyster mushroom by-products diet decreased WBSF and cooking loss but increased CP content, WHC and lightness (CIE L ${ }^{*}$ ) of LD muscles in fattening pigs. Substitution of fermented king oyster mushroom by-products diet was not observed on $\mathrm{pH}$, TBARS and VBN but was determined on the lightness and yellowness of LD muscle during 1 or $7 \mathrm{~d}$ of storage. Therefore, further investigation is required to clarify the effects of fermented king oyster mushroom by-products diet on the mechanisms of meat quality and its relation to sensory evaluation for meat consumers.

\section{Acknowledgments}

This work was supported by Priority Research Centers Program through the National Research Foundation of Korea (NRF) funded by the Ministry of Education, Science and Technology (2009-0093813) and Cooperative Research Program for Agriculture Science \& Technology Development (Project No.PJ0077672011) by Rural Development Administration, Republic of Korea.

\section{Referances}

1. Association of Official Analytical Chemists (AOAC) (1995) Official method of analysis. 16th ed., AOAC, Washington, DC.

2. Bae, J. S., Kim, Y. I., Jung, S. H., Oh, Y. G., and Kwak, W. S. (2006) Evaluation on feed-nutritional value of spent mushroom (Pleurotus osteratus, Pleurotus eryngii, Flammulina velutupes) substrates as a roughage source for ruminants. Korean J. Anim. Sci. Technol. 48, 237-246.

3. Bourne, M. C. (1978) Texture profile analysis. Food Tech. 32, 62-66.

4. Chu, G. M., Yang, B. S., Kim, H. Y., Kim, J. H., Ha, J. H., Kim, C. H., Lee, S. D., and Song Y. M. (2011) Effects of supplemental fermented agro by-products diet on the growth performances, blood characteristics and carcass traits in fattening pigs. Asian-Aust. J. Anim. Sci. 24, 1464-1472.
5. Darmadji, P. and Izumimoto, M. (1994) Effect of chitosan in meat preservation. Meat Sci. 38, 410-416.

6. French, P., Stanton, C., Lawless, F., O'Riordan, E. G., Monahan, F. J., Caffrey, P. J., and Moloney, A. P. (2000) Fatty acid composition, including conjugated linoleic acid of intramuscular fat from steers offered grazed grass, grass silage, or concentrate-based diets. J. Anim. Sci. 78, 2849-2855.

7. Honikel, K. O. (1998) Reference methods for the assessment of physical characteristics of meat. Meat Sci. 49, 447-457.

8. Huang, Y. X. and Miller, E. L. (1993) Iron-induced TBARS as an indicator of oxidative stability of fresh chicken meat. In Proceedings of the 11th European symposium on the quality of poultry meat. pp 430-434, Tours, France.

9. Kang, S. N., Song, Y. M., Kim, C. W., Kim, T. W., Chu, G. M., Yang, B. S., Jin, S. K., and Kim, I. S. (2010) Effect of feeding high carbohydrate-low fat fermented feed on the meat quality characteristics in finishing pigs. Korean J. Food Sci. Ani. Resour. 30, 826-832.

10. Kim, Y. I., Bae, J. S., Jung, S. H., Ahn, M. H., and Kwak, S. K. (2007) Yield and physicochemical characteristics of spent mushroom (Pleurotus ryngii, Pleurotus osteratus and Ammulina velutipes) substrates according to mushroom species and cultivation types. Korean J. Anim. Sci. Technol. 49, 79-88.

11. Kwak, W. S., Jung, S. H., and Kim, Y. I. (2008) Broiler litter supplementation improves storage and feed-nutritional value of sawdust-based spent mushroom substrates. Biores. Technol. 99, 2947-2955.

12. Lawrie, R. (1985) Packaging resh meat. In. Development in meat science, Taylor, A. A. Elsevier Applied Science Publisher. p 89.

13. Lee, S. D., Kim, H. Y., Jung, H. J., Ji, S. Y., Chowdappa, R., Ha, J. H., Song, Y. M., Park, Y. M., Park, J. C., Moon, and H. K., Kim, I. C. (2009) The effect of fermented apple diet supplementation on the growth performance and meat quality in finishing pigs. Anim. Sci. J. 80, 79-84.

14. Lee, S. Y., Han, J. H., Cho, S. H., Kim, A. R., Kim, J. H., Park, S. M., and Ahn, D. H. (2006) Effect of film with watersoluble chitosan packaging on shelf-life and quality of pork lion. J. Chitin Chitosan 11, 228-236.

15. Liu, S., Han, Y., and Zhou, Z. (2011) Lactic acid bacteria in traditional fermented Chinese foods. Food Res. Int. 44, 643651.

16. Meilgaard, M., Civille, G. V., and Carr, B. T. (1991) Affective tests: Consumer tests and in-house panel acceptance tests. In: Sensory evaluation techniques. 3rd edn, CRC Press Inc, Boca Ranton, FL, pp 211-222.

17. Pearson, D. (1976) The Chemical Analysis of Foods, 7th ed. Churchill, Livingston. p 386.

18. Pettigrew, J. J. E. and Moster, R. L. (1991) Fat in swine nutrition. Miller, R., Ullrey, D. E., and Lewis, A. J. Edn. Swine Nutrition. Butterworth-Heinemann, Stoneham MA. pp 133146.

19. Platter, W. J., Tatum, J. D., Belk, K. E., Chapman, P. L., Scanga, J. A., and Smith, G. C. (2003) Relationships of consumer sensory ratings, marbling score, and shear force value to consumer acceptance of beef strip loin steaks. J. Anim. Sci. 
81, 2741-2750.

20. Risvik, E. (1994) Sensory poperties and preferences. Meat Sci. 36, 67-77.

21. Shield, R. G., Mahan, D. C., and Graham, P. L. (1983) Changes in swine body composition from birth to $145 \mathrm{~kg}$. $J$. Anim. Sci. 57, 43-54.

22. Song, Y. M., Chu, G. M., Ha, J. H., Lee, H. J., Kim, S. C., and Kim, H. Y. (2011) Effects of fermented diet using probiotics from pine needle microbes on growth performance, blood characteristics, carcass traits and economy of pigs. J. Agric. Life Sci. 45, 93-101.

23. Song, Y. M., Lee, S. D., Chowdappa, R., Kim, H. Y., Jin, S. K., and Kim, I. S. (2007) Effects of fermented oyster mushroom (Pleurotus ostreats) by-product supplementation on growth performance, blood parameters and meat quality in finishing Berkshire pigs. Anim. 1, 301-307.

24. SAS (1999) SAS/STAT Software for PC. Release 8.0, SAS IInstitute Inc., Cary, NC, USA.
25. Steinkraus, K. H. (1996) Introduction to indigenous fermented foods. In: Steinkraus KH (Edn), Handbook of indigenous fermented foods. New York, Marcel Dekker, pp. 1-6.

26. Szczceniak, A. S. (1963) Classification of textural characteristics. J. Food Sci. 28, 385-389.

27. Texture Technologies. 2003. Textural profile analysis explained \& annotated. http://www.texturetechnologies.com/texture profile_analysis. html. Accessed Dec. 10, 2011.

28. Way, P. and Hanahan, D. J. (1964) Characterization and quantification of red cell lipids. J. Lipid Res. 5, 318-328.

29. Williams, B. C., McMullan, J. T., and McCahey, S. (2001) An initial assessment of spent mushroom compost as a potential energy feedstock. Biores. Technol. 79, 227-230.

30. Wyszcecki, G. and Stiles, W. S. (1982) Color science (2nd edn.). Concepts and method, quantitative data and formula. New York, John Wiley.

(Received 2012.1.9/Revised 2012.3.11/Accepted 2012.3.13) 